\title{
A Right-of-Way Stormwater Low Impact Development Practice
}

\author{
James Li, ${ }^{1}$ Darko Joksimovic ${ }^{1}$ and John $\operatorname{Tran}^{2}$ \\ ${ }^{1}$ Ryerson University, Toronto; ${ }^{2}$ obiit.
}

Received 2015-04-22, accepted 2015-07-14, published 2015-08-21.

\begin{abstract}
Road right-of-way can provide a good retrofit opportunity to implement stormwater low impact development (LID) technologies. In Canada and the northern United States, stormwater management should focus not only in summer and fall but also winter and spring. A stormwater exfiltration system was designed to manage stormwater over four seasons by retrofitting roads with two 200 $\mathrm{mm}$ perforated pipes with ends capped below a storm sewer system. The design concept is to direct road runoff of up to $15 \mathrm{~mm}$ rainfall to these two perforated pipes and fill the void space of the sewer trench for exfiltration to the surround soil at all times (i.e. including snowmelts and rainfalls during winter and the early spring seasons). In 1993, $2.5 \mathrm{~km}$ of this exfiltration system was constructed in Etobicoke, Toronto, and subsequent monitoring results indicated that a long duration rainfall, $\leq 28 \mathrm{~mm}$ over $22.5 \mathrm{~h}$, was almost completely captured without overflowing to the storm sewer above. This paper presents the planning and design criteria, construction and maintenance, performance evaluation, and costs of this LID based on the Etobicoke application.
\end{abstract}

\section{Introduction}

Road reconstruction or sewer replacement, continuously being done in municipalities, can provide an opportunity to implement LID at existing urbanized area. An innovative LID technology, termed the Etobicoke Exfiltration System (EES), was developed and implemented in Etobicoke, Toronto $>20$ y ago. Conceived to reproduce the infiltration and groundwater recharge of rainfall prior to urbanization, the EES consisted of two $200 \mathrm{~mm}$ perforated PVC pipes which were installed below the storm sewer as the road was reconstructed (Figure 1).

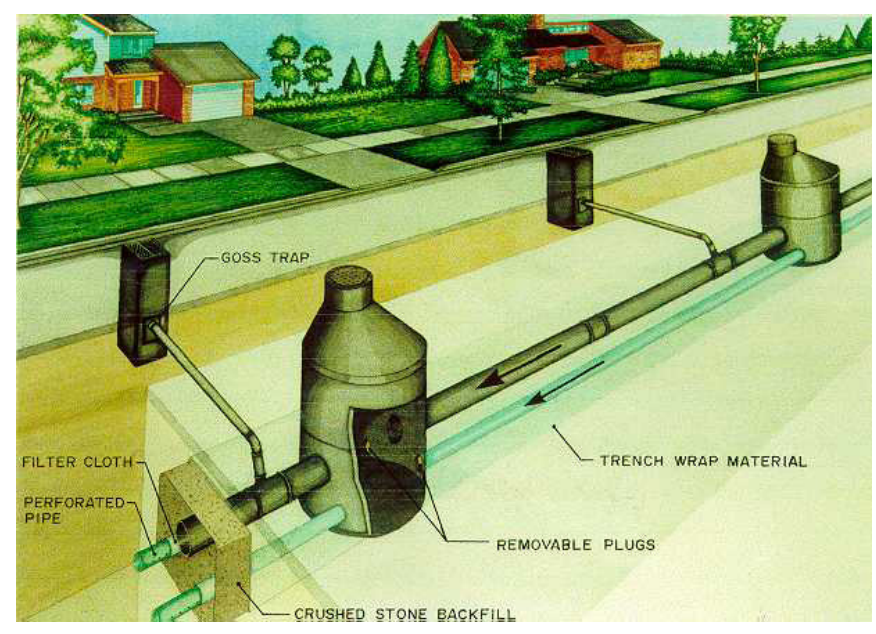

Figure 1 Concept of Etobicoke exfiltration system.
Both the perforated pipes and the storm sewer were encased in a granular stone trench. The perforated pipes are connected to both the upstream and downstream manholes below the storm sewers. At the downstream manhole, mechanical plugs were installed at the exfiltration pipes. Thus the exfiltration pipes were storage systems instead of conveyance systems. During a storm event, storm runoff from the upstream manhole enters the two perforated pipes and then exfiltrates firstly to the stone trench and subsequently to the surrounding soil. In order to prevent the perforated pipes and stone trench from clogging, sediment intrusion, or loss of granular materials, both the perforated pipes and the stone trench were wrapped with a filter fabric.

For large storm events, the runoff may exceed the exfiltration volume and the storage capacity of the perforated pipes and stone trench, resulting in an overflow to the storm sewer at the upstream manhole. Since EES was situated below the storm sewer (usually below the frost line in Canada), it would not be frozen in winter and early spring and continues to work during snowmelts throughout winter and early spring.

A demonstration project of $2.5 \mathrm{~km}$ of EES was implemented in 1993 at two existing residential areas and found to be effective in reducing storm runoff of up to $63 \mathrm{~mm}$ ( $18 \mathrm{~h}$ ) of rainfall events. This paper presents the planning and design criteria, construction and maintenance, performance evaluation, and costs of EES based on the Etobicoke application. Although EES was constructed and monitored 20 y ago (the only one in the world), the planning and design procedure was never summarized until the

Li, J., D. Joksimovic and J. Tran. 2015. "A Right-of-Way Stormwater Low Impact Development Practice." Journal of Water Management Modeling C390. doi: 10.14796/JWMM.C390.

(C) CHI 2015 www.chijournal.org ISSN: 2292-6062 
recent development of a planning and design manual by Li and Tran (2015).

Recent research works (Liu 2015) at Ryerson University, Toronto indicate that EES could potentially eliminate the requirement of stormwater quality ponds for new residential developments in Ontario. As a result, this paper contributes to the first knowledge transfer of EES and the future stormwater management across Canada.

\section{Planning}

\subsection{Stormwater Management Objectives}

In Ontario, the Ministry of the Environment and Climate Change's (MOECC) Stormwater Management Planning and Design Manual (MoE 2003) describes the following five stormwater management criteria:

1. Preserve groundwater and baseflow characteristics;

2. Prevent undesirable and costly geomorphic changes in watercourses;

3. Prevent any increase in flood potential;

4. Protect water quality; and ultimately; and

5. Maintain an appropriate diversity of aquatic life and opportunities for human use.

Ternier (2013) developed a set of comprehensive stormwater management objectives and identified those that can potentially be addressed by EES. Tables 1 and 2 summarize the environmental and human habitat objectives that determine the suitability of EES. (A more detailed explanation of those objectives can be found in Ternier 2013.)

Table 1 Environmental and aquatic objectives (Ternier 2013).

\begin{tabular}{|c|c|c|}
\hline $\begin{array}{l}\text { Environmental } \\
\text { Objectives }\end{array}$ & Suitability & EES Actions \\
\hline $\begin{array}{l}\text { Preserve ground- } \\
\text { water }\end{array}$ & Yes & Infiltrate $90 \%$ of rainfall events \\
\hline $\begin{array}{l}\text { Preserve baseflow } \\
\text { characteristics }\end{array}$ & Yes & $\begin{array}{l}\text { Recharge groundwater according to duration and } \\
\text { frequency dictated by rain events }\end{array}$ \\
\hline Protect water quality & Yes & $\begin{array}{l}\text { Lower discharge of pollutants to streams/lakes during } \\
\text { four seasons }\end{array}$ \\
\hline $\begin{array}{l}\text { Maintain aquatic } \\
\text { and terrestrial } \\
\text { biodiversity }\end{array}$ & Yes & $\begin{array}{l}\text { Maintain pre-development groundwater level by } \\
\text { enhancing source infiltration }\end{array}$ \\
\hline $\begin{array}{l}\text { Protect spawning } \\
\text { and rearing grounds }\end{array}$ & Highly Yes & $\begin{array}{l}\text { Maintain baseflow, lower sediment loading, lower } \\
\text { temperature }\end{array}$ \\
\hline $\begin{array}{l}\text { Protect migratory } \\
\text { corridors }\end{array}$ & Yes & Maintain natural pools and riffles \\
\hline Protect wetlands & Highly Yes & Maintain a constant baseflow to the wetland \\
\hline $\begin{array}{l}\text { Minimize impacts of } \\
\text { climate changes }\end{array}$ & Yes & Underground storage provides cooler temperatures \\
\hline
\end{tabular}

Table 2 Human habitat objectives (Ternier 2013)

\begin{tabular}{|c|c|c|}
\hline Human habitat objectives & $\begin{array}{l}\text { Suitabil- } \\
\text { ity }\end{array}$ & EES Actions \\
\hline Drinking water & No & $\begin{array}{l}\text { Potential contamination of drinking water } \\
\text { source }\end{array}$ \\
\hline New Residential sites & Yes & $\begin{array}{l}\text { Potential elimination o the need for quality } \\
\text { ponds and associated safety concerns }\end{array}$ \\
\hline New Industrial sites & No & $\begin{array}{l}\text { Potential industrial contamination of } \\
\text { groundwater }\end{array}$ \\
\hline Combined sewers & Yes & $\begin{array}{l}\text { Same installation as storm sewers and } \\
\text { reduction of runoff to combined sewers. }\end{array}$ \\
\hline Retrofit existing residential sites & Yes & $\begin{array}{l}\text { Provide water quality control and flood } \\
\text { control where not provided previously }\end{array}$ \\
\hline Retrofit existing industrial sites & No & Same concerns as new industrial sites \\
\hline Residential local roads & Yes & $\begin{array}{l}\text { Eliminate need for quality ponds and } \\
\text { associated safety concerns }\end{array}$ \\
\hline Residential collectors & Yes & $\begin{array}{l}\text { Eliminate need for quality ponds and } \\
\text { associated safety concerns }\end{array}$ \\
\hline Residential arterial & No & Spill and structural concerns \\
\hline Industrial roads & No & $\begin{array}{l}\text { Potential industrial contamination of } \\
\text { groundwater }\end{array}$ \\
\hline $\begin{array}{l}\text { Prevent any increase in flood } \\
\text { potential }\end{array}$ & Yes & Reduce peak flow and runoff volume \\
\hline Prevent geomorphic changes & Yes & Stabilize urban peak flow during four seasons \\
\hline
\end{tabular}

\subsection{Suitability Screening}

A two step screening procedure has been developed for the EES (Li and Tran 2015). The first step comprises the following most critical screening questions:

1. Is a water supply aquifer absent at the site of interest (reduced ground water contamination)?

2. Is the site of interest a low density residential area (less polluted runoff)?

3. Is the site of interest served by local roads (reduced spill potential by industrial trucks and structural consideration of perforated pipes)?

4. Is the ground water table below the invert of the exfiltration pipes?

All of the first step questions must be answered affirmatively without exception in order to continue to the second step. Regarding question 4, the EES can still be considered suitable even the ground water table is $<1 \mathrm{~m}$ (typical for infiltration or exfiltration devices) because runoff will be exfiltrated horizontally along the storm sewer trench in addition to vertically downward.

The second step comprises the following secondary screening questions:

1. Are the roads or sewers in poor condition (increased retrofit potential and saved cost)?

2. Is the tree root problem absent at the site of interest (trees with deep roots need relocation to prevent 
roots from damaging filter cloth and perforated pipes)?

3. Is the required maintenance equipment available at the municipality (reduced long term maintenance cost)?

All of the second step questions should be answered affirmatively, either with or without implementation of engineering measures designed to remedy the associated environmental impacts. If there are additional environmental impacts associated with the engineering measures, then the EES is not suitable for the site of interest.

\section{Design}

\subsection{Design Criteria}

In order to satisfy the municipal sewer design requirements, the design criteria of EES were selected as follows: storm sewers were sized to convey a typical 2 y or 5 y design storm; and the pipetrench system (the two pipe volumes plus the void space in the trench up to the storm sewer invert level) was designed to store the runoff volume of a $15 \mathrm{~mm}$ design storm (corresponding to the 90th percentile of storm event volume in Toronto; the application of EES at other locations should consider their corresponding 90th percentile of storm event volume).

\subsection{Design Specifications}

At the demonstration site, storm sewers were designed using the conventional Rational Method. Using a $1 \mathrm{~h}$ Canadian Atmospheric Environment Service (AES) design storm (15 mm rainfall event volume), the corresponding runoff hydrograph from the catchment was simulated using the MIDUSS program (Alan A. Smith Inc. 2009). The geotechnical investigation of the soil at the sites indicated a saturated hydraulic conductivity between $10^{-9} \mathrm{~m} / \mathrm{s}$ and $10^{-8} \mathrm{~m} / \mathrm{s}$ (Candaras 1997). Thus, it was assumed that the exfiltration volume during the storm event was negligible.

The combined volume of the perforated pipes and the void space of the trench was then sized to accommodate the runoff volume. As a result, each section of EES might be different depending upon the drainage areas. At the demonstration sites (low density residential area), the average runoff volume of a 15 $\mathrm{mm}$ AES storm was estimated to be $\sim 5 \mathrm{~mm}$. Figure 2 shows the orientation of the $12 \mathrm{~mm}$ orifices while Figure 3 shows the cross sectional details of EES. Standard cutoff walls (OPSD 812.010 2006, https://www.raqsb.mto.gov.on.ca/techpubs/ops.nsf/OPSHomepage), constructed laterally at the downstream manhole of each section of EES, force the exfiltration laterally to both sides of the stone trench. The material specifications of EES were: 200 mm Type PSM PVC pipes (ASTM: D3034-04a, http://www.astm. org/DATABASE.CART/HISTORICAL/D3034-04A.htm); nonwoven geotextile pipe socks; 19 mm clear aggregates (Granular B Type II); and construction rubber and ABS plastic pipe plugs, mechanical, nominal size $200 \mathrm{~mm}$ (maximum back pressure $\leq 40 \mathrm{ft}, 12.19 \mathrm{~m}$, head).

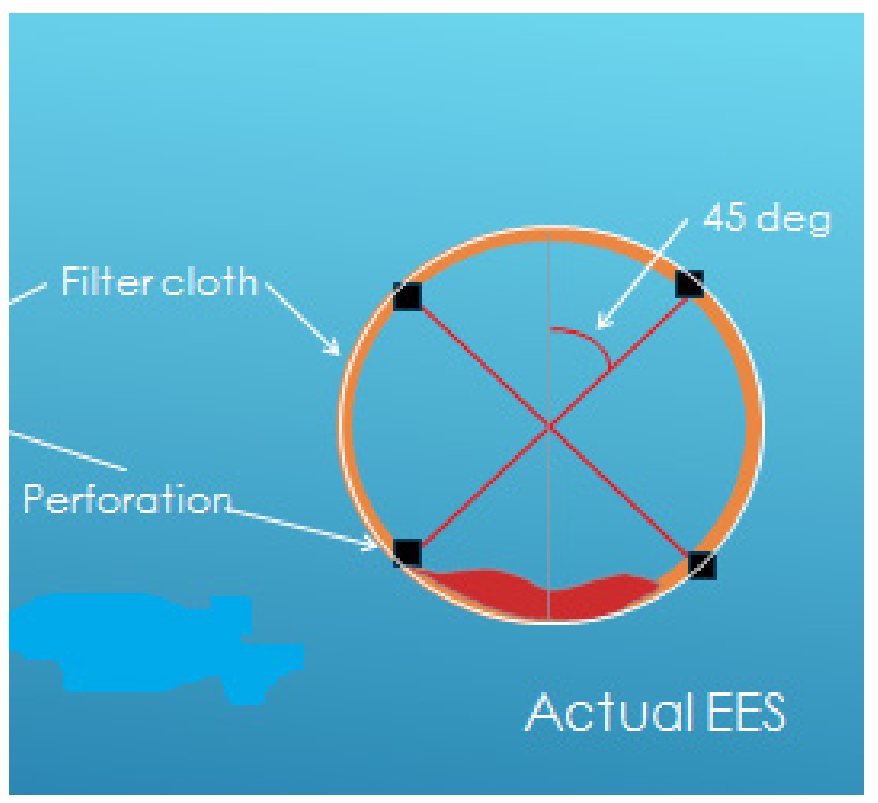

Figure 2 Orientation of $12 \mathrm{~mm}$ perforations.

Etobicoke Exfiltration System

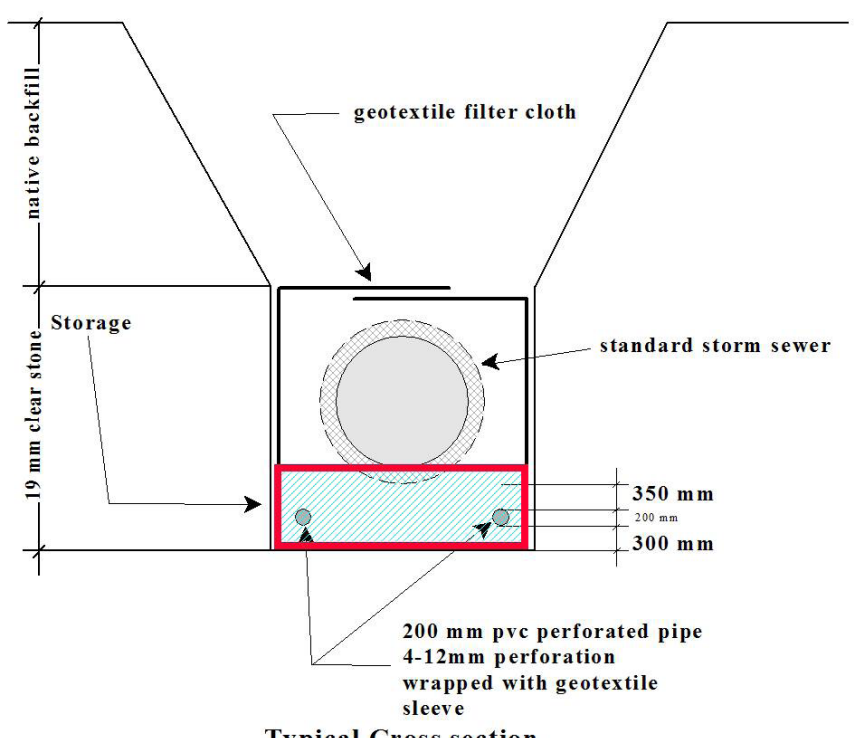

Typical Cross section

Figure 3 Cross sectional details of EES.

\section{Construction}

Before construction, all necessary erosion and sediment control devices were installed to prevent sediment laden runoff from leaving the construction sites and entering the exfiltration pipes. The construction procedure of EES is listed below:

1. Excavation of the trench was undertaken using standard construction techniques; 
2. Nonwoven filter cloth was placed around the trench and held on the sides of the trench by stakes;

3. Clear Granular B aggregates of $19 \mathrm{~mm}$ size were placed from the bottom of the trench to the design invert of the perforated pipes;

4. Two $200 \mathrm{~mm}$ perforated pipes (at about $0.5 \%$ grade) wrapped with nonwoven filter pipe sockets were placed on the Granular B aggregates and construction plastic pipe plugs were placed on both upstream and downstream ends;

5. Granular B aggregates were placed over and around the perforated pipes until the elevation of the invert of the sewer was reached;

6. The storm sewer was laid above the granular layer;

7. Catchbasins were installed with leaders connected to the sewers;

8. Granular B aggregates were placed over and around the sewers;

9. The nonwoven filter cloth was wrapped over the granulars with an overlapping width of $1 \mathrm{~m}$;

10. The trench was then backfilled with suitable soils; and

11. The mechanical plugs at the upstream end of each section of the EES were removed after all construction.

Figures 4 to 10 show the pictures of the above procedure.

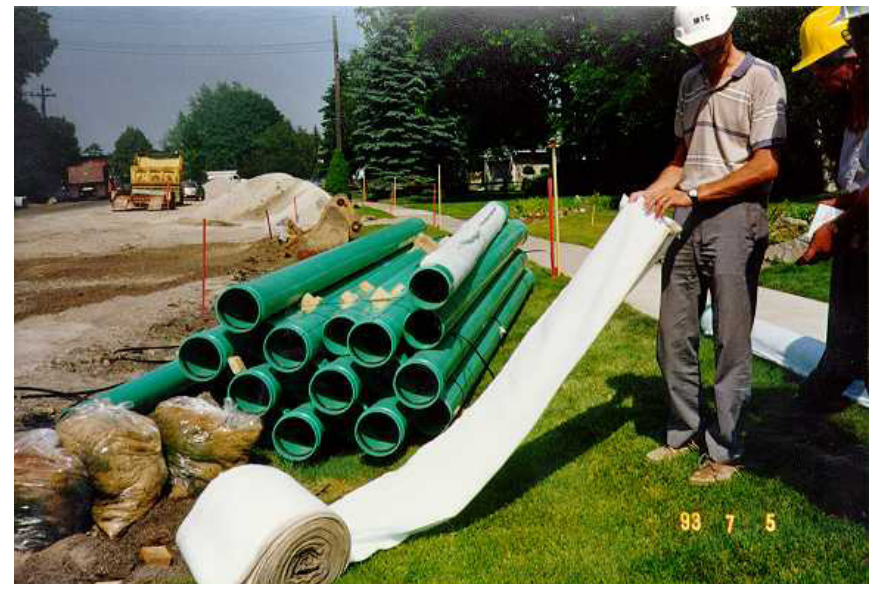

Figure 4 Exfiltration pipes wrapped with nonwoven filter pipe socks.

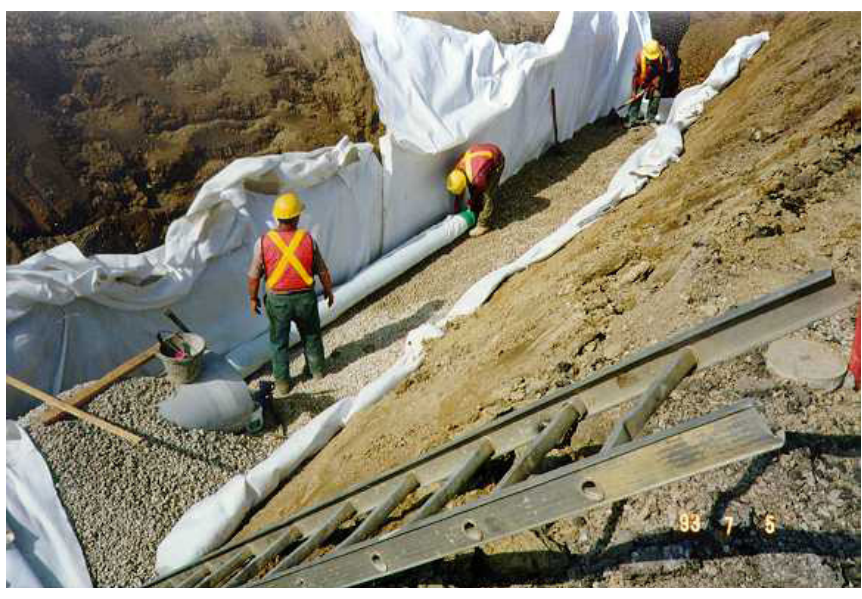

Figure 5 Laying the exfiltration pipes.

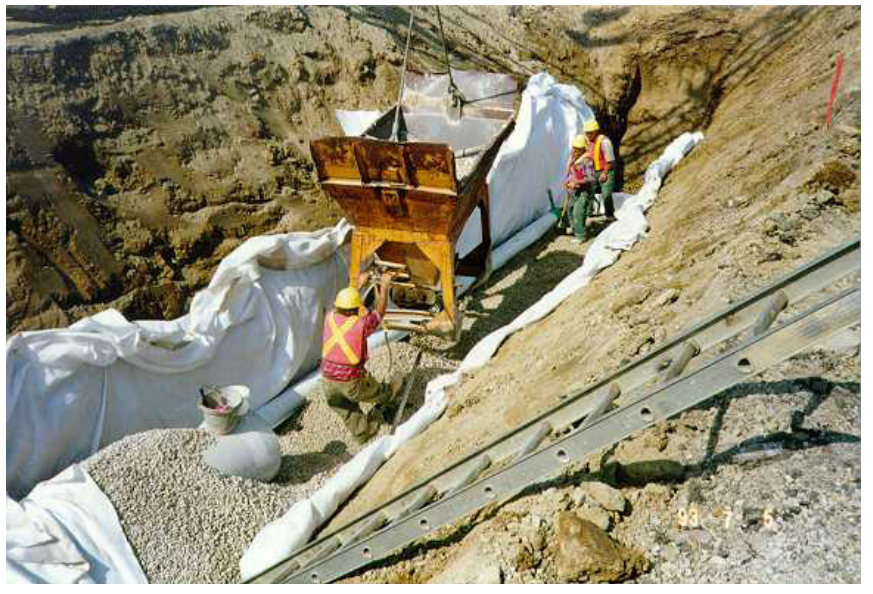

Figure 6 Backfilling the perforated pipes.

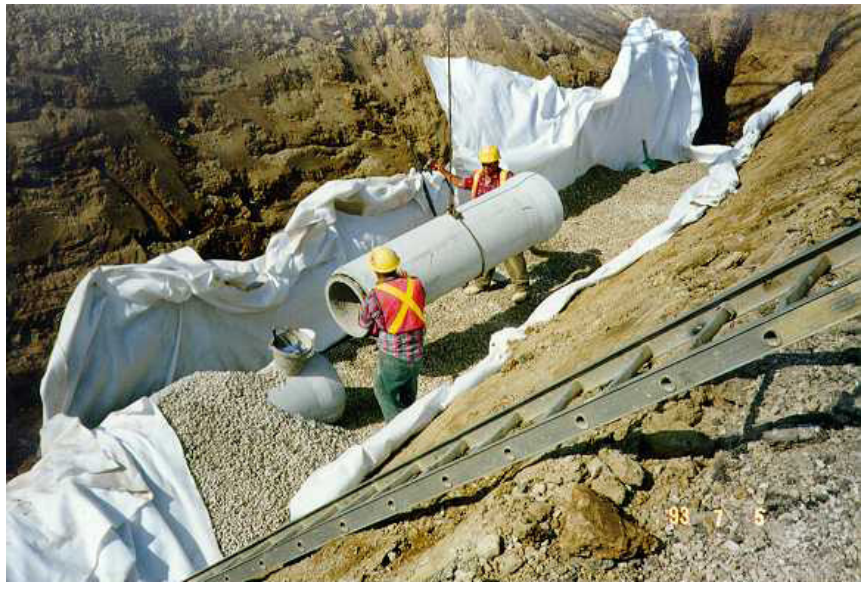

Figure 7 Laying the concrete storm sewers. 


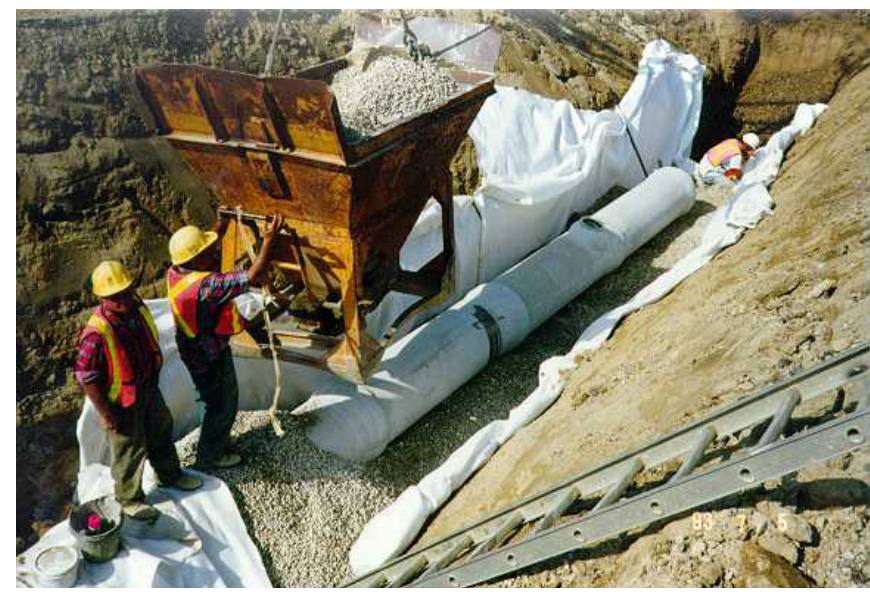

Figure 8 Backfilling the storm sewers.

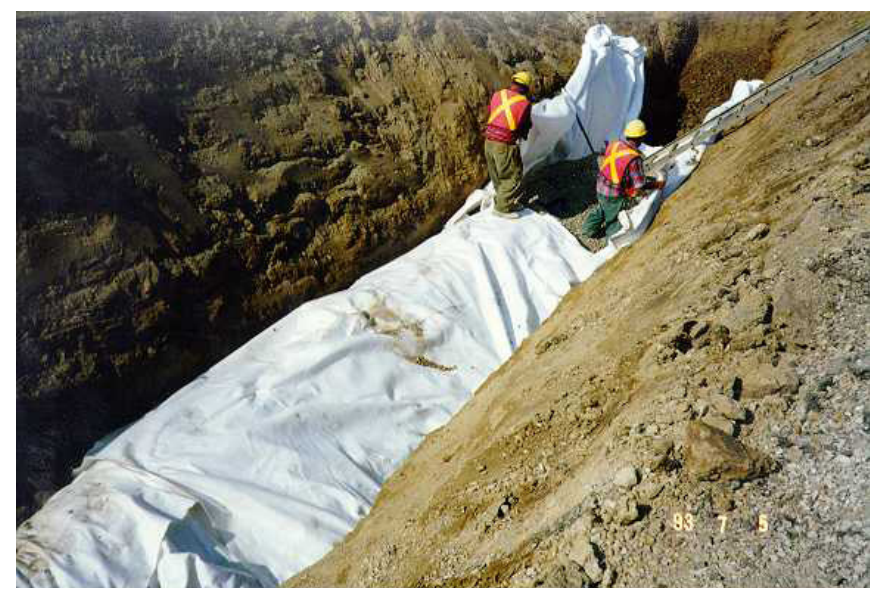

Figure 9 Wrapping the granular trench with nonwoven filter

cloths.

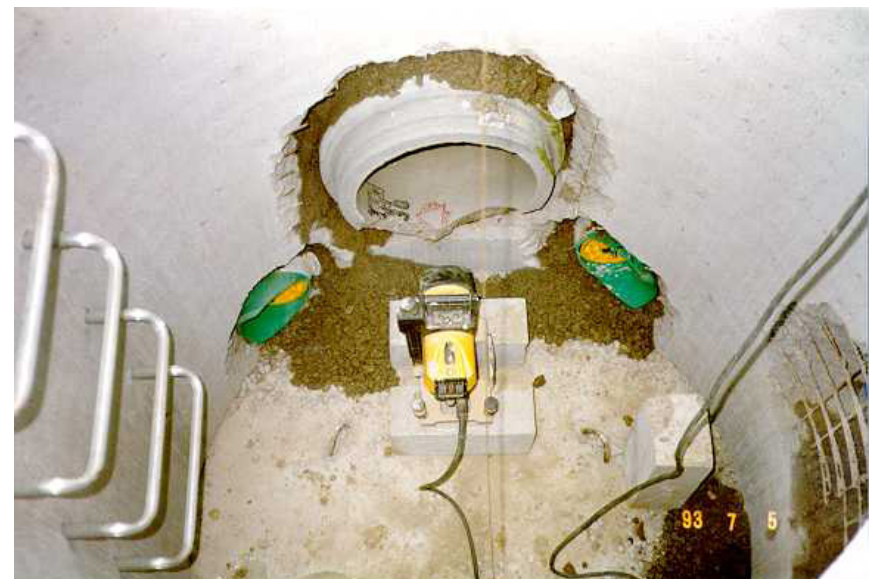

Figure 10 Construction of PVC pipe plugs at both sites of

the perforated pipes.

\section{Maintenance}

Post-construction maintenance includes the following.

\section{A Regular Maintenance and Observation Program}

A regular observation and maintenance program was conducted at the two demonstration sites. The working conditions of the EES were assessed periodically and after major storm events during the first $2 \mathrm{y}$. General observations included visual evidence of overflows at the sewer, water marks along the sewer and near manholes, and the integrity of the mechanical plug at the downstream end of the perforated pipes. If a small storm event had caused an overflow or a high water level at the upstream manhole, the EES might be plugged and needed cleaning. If the downstream mechanical plug had been pushed out, a short circuit of flow at that length of perforated pipes might have occurred. Additionally, minor deficiencies such as debris accumulation at catch basins were identified and repaired. Figure 11 shows the upstream and downstream water marks of the $1.3 \mathrm{~km}$ storm sewer system. Most of the upstream sections of the sewer had no overflow, indicating the EES had intercepted the runoff completely. In order to assess the sediment accumulation inside the perforated pipes, a video inspection was conducted in both the first and the second year after construction. It was observed (Figure 12) that a small amount of sediment accumulated at the downstream end of the perforated pipes, and some organic materials such as leaves clung to the obvert of the perforated pipes. The concentration of sediments at the downstream end of each section is attributed to the sloping exfiltration pipes $(\sim 0.5 \%)$ which pushed the sediments downstream. Thus periodic cleaning of the perforated pipes is required. Even if the accumulated sediment is not removed, the upstream section of EES will still exfiltrate runoff to the granular trench. In fact, the EES at the demonstration site has not been cleaned after $>20$ y and there have been no reports of significant overflows at the site.

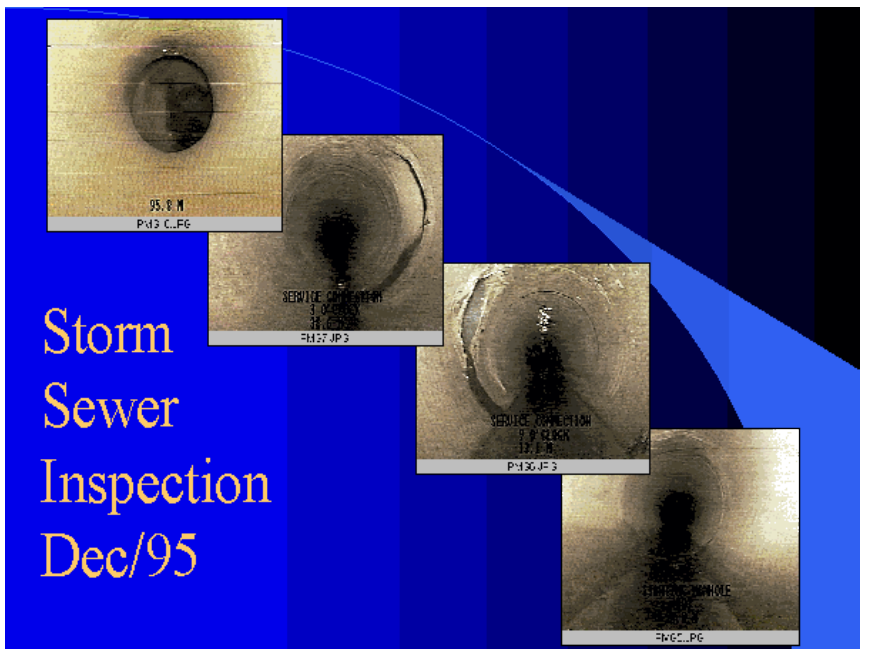

Figure 11 Water marks from the upstream to downstream sections of the storm sewer system. 

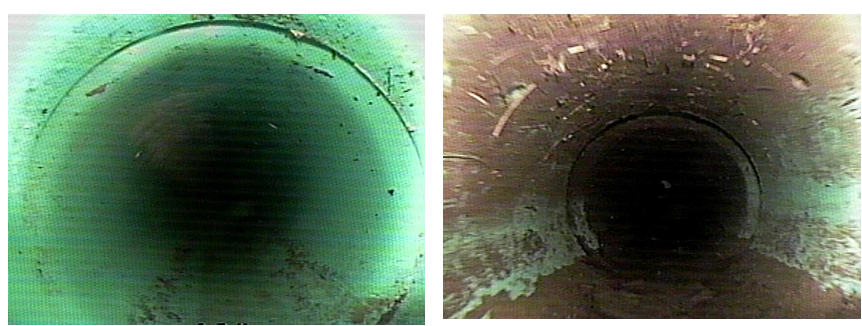

1994-07 Upstream 3.5 m

1994-07 Downstream $98.4 \mathrm{~m}$

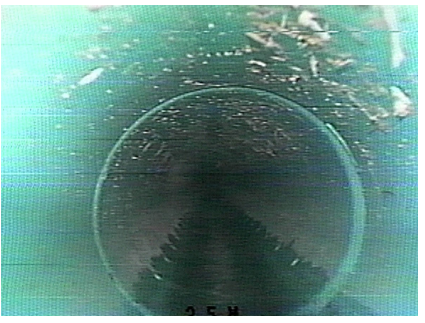

1995-12 Upstream 3.7 m

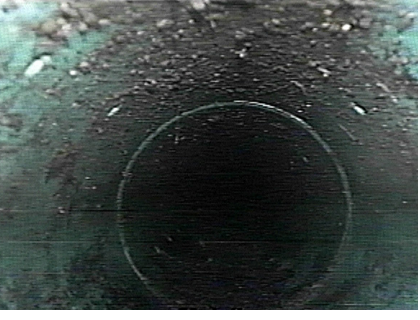

1995-12 Downstream $73.1 \mathrm{~m}$

Figure 12 Sediment accumulation at upstream and downstream parts of the perforated pipes of two EES sections.

Power Flushing the Perforated Pipes to Remove Accumulated Sediments

Although the sediment accumulated inside the perforated pipes was small, a demonstration of the potential cleaning techniques was conducted $1 \mathrm{y}$ after the construction. The downstream mechanical plugs of an upper section of the EES were first removed and a highly pressurized water flusher was inserted at the downstream end. The flusher discharged pressurized jets of water that scoured the walls of the perforated pipes as it travelled upstream. The accumulated sediments were flushed to the downstream manhole of the section and were then pumped out using a vacuum truck. The sediments were then removed from the water using a treatment truck equipped with a shear drum separator and disposed of offsite.

Since the demonstration, there has been no report of maintenance of the EES at the site. However, this demonstration has served the purpose of showing potential cleanup technologies that can be employed by municipalities. Depending on the sediment accumulation observed, it is recommended that flushing be conducted once the exfiltration pipes are found to be half filled up with sediments.

\section{Performance}

Figure 13 shows the EES performed effectively for the 1994-05-26 event with a rainfall volume of $28.3 \mathrm{~mm}$ over $22.5 \mathrm{~h}$. There was hardly any flow at downstream manhole 3 (green hydrograph) of an EES section, indicating the majority of the runoff event (red hydrograph) got captured by the perforated pipes and stone trench. Additionally, the stone filter head at manhole 3 was high compared to that at manhole 2 , indicating runoff was trapped

downstream at the stone trench. A summary of the monitoring results is shown in Tables 3 and 4.

Princess Margaret Blvd. May 26,1994

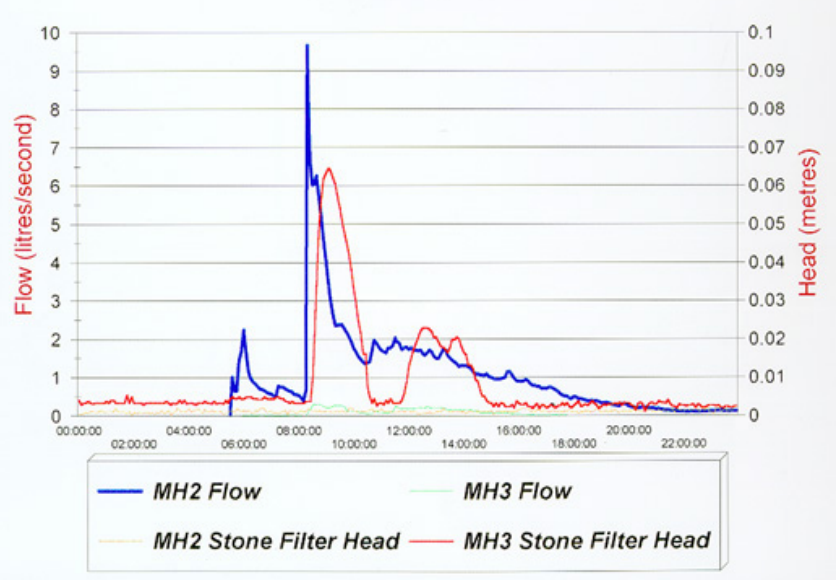

Figure 13 Flows at upstream manhole 2 (blue) and downstream manhole 3 (green) during 1994-05-26 event.

Table 3 Peak inflow and peak outflow of EES at the upstream section.

\begin{tabular}{cccccc}
\hline Date & $\begin{array}{c}\text { Rainfall } \\
(\mathrm{mm})\end{array}$ & $\begin{array}{c}\text { Peak } \\
\text { inflow } \\
(\mathrm{L} / \mathrm{s})\end{array}$ & $\begin{array}{c}\text { Peak outflow } \\
(\mathrm{L} / \mathrm{s})\end{array}$ & $\begin{array}{c}\text { Upstream filter } \\
\text { head }(\mathrm{mm})\end{array}$ & $\begin{array}{c}\text { Downstream } \\
\text { filter head }(\mathrm{mm})\end{array}$ \\
\hline $1994-05-26$ & 28.3 & 9.7 & 0.3 & Nil & 65 \\
$1994-05-31$ & 11.1 & 8.1 & 1.5 & Nil & 5 \\
$1994-06-24$ & 24.1 & 2.2 & 0.1 & Nil & 3 \\
$1995-10-05$ & 63.0 & 10.0 & 3.0 & 380 & 500 \\
\hline
\end{tabular}

Table 4 Overflow frequency of EES at the upstream section.

\begin{tabular}{rccc}
\hline Date & Rainfall $(\mathrm{mm})$ & Duration (hrs) & $\begin{array}{c}\text { Overflow to storm } \\
\text { sewer }\end{array}$ \\
\hline $1994-05-26$ & 28.3 & 22.5 & No \\
$1994-05-31$ & 11.1 & 0.5 & No \\
$1994-06-24$ & $24.1 \mathrm{~m}$ & 24 & No \\
$1994-09-25$ & 19.1 & 1.5 & No \\
$1995-10-05$ & 63.0 & 18.0 & Yes \\
$1996-10-18$ & 26.7 & 14.0 & No \\
$1996-11-08$ & 18.0 & 10.0 & No \\
$1997-08-15$ & 20.8 & 4.0 & No \\
$1997-09-10$ & 16.0 & 10.0 & No \\
$1997-11-01$ & 23.0 & 10.1 & No \\
$1998-05-11$ & 42.8 & 48.0 & No \\
$1998-06-11$ & 23.8 & 7.0 & No \\
$1998-06-30$ & 26.8 & 2.5 & Yes \\
$1998-09-06$ & 15.3 & 0.75 & Yes \\
\hline
\end{tabular}

${ }^{1} 0$ verflow occurred after $8 \mathrm{~h}$ and half of the total runoff passed.

No monitored events caused an overflow to the storm sewer except the largest storm and the last two short duration high 
intensity storms. It is noted that the large event on 1995-10-05 (63 $\mathrm{mm}$ over $18 \mathrm{~h}$ ) did not cause an overflow until $8 \mathrm{~h}$ had elapsed and $50 \%$ of the runoff volume occurred, while the smaller events on 1998-06-30 (26.8 mm over $2.5 \mathrm{~h}$ ) and 1998-09-06 (15.3 mm over $0.75 \mathrm{~h}$ ) caused overflows. Given enough times for exfiltration (e.g. long duration storms), even very large events (e.g. $63 \mathrm{~mm}$ ) can be substantially captured by EES. On the other hand, short duration storms can trigger overflow due to high runoff rates compared to the exfiltration rate along the EES. No winter and spring melt events were ever monitored at the demonstration site. Since the EES is below the sewer and the frost line, it should be able to intercept any snowmelt during winter and early spring. Compared to LID on the surface, which may be frozen during winter, EES will offer stormwater management over winter and early spring.

\section{Cost}

Table 5 shows the cost breakdown of the EES at Princess Margaret Street in 1993 dollars. The costs of road, drainage, and EES are $78 \%, 18 \%$, and $4 \%$ respectively. If a stormwater quality pond was used to control the runoff from the site (30.5 hectares), the construction cost would be about $\$ 130000$ (about $\$ 30 / \mathrm{m}^{3}$ in 1993 dollars excluding land cost). Compared to the cost of EES (\$25 000), a saving of about $80 \%$ could be realized. It is noted that the reconstruction of the sewer at Princess Margaret Street involved open cut trenches. If trench boxes were used, the excavation cost might be reduced. Thus the cost saving of EES as a percentage of the total road reconstruction cost may be greater."

Table 5 Cost breakdowns of EES (Karakis 1999).

\begin{tabular}{lr}
\hline \multicolumn{1}{c}{ Description } & Cost (\$) \\
\hline Drainage including sewers, manholes and labour & 122531.20 \\
EES including perforated pipes, filter cloth, plugs, and labour & 25033.60 \\
Road construction including catch basins and labour & 533990.60 \\
Total project & 681555.40 \\
Monitoring & 120000.00 \\
\hline
\end{tabular}

\section{Conclusions}

EES is a road right-of-water LID that can capture substantial runoff from small and medium events over four seasons. If it is located in good drainage soil, the captured runoff can be dissipated to the surrounding soil laterally along the storm sewer. It is particularly appropriate for roads or sewers which are scheduled to be rehabilitated because the additional cost (e.g. $4 \%$ in the Toronto demonstration site) is relatively small compared to the road or sewer construction costs. While the design of the storm sewer above the EES follows a typical municipal standard, EES can actually reduce the flow to the storm sewer. As a result, the storm sewer can be reduced in size if agreed by a municipality. Ultimately, EES can reduce or even replace any stormwater quality pond downstream. Future works should be done to optimize the design of EES in terms of runoff capture, monitor its performance over winter and early spring seasons, and conduct a full life cycle cost reduction analysis.

\section{Acknowledgment}

This paper is dedicated to the original designer of EES, the late John Tran, whose revolutionary ideas have inspired a lot of stormwater professionals in Ontario and elsewhere in Canada. We would like to acknowledge the support and contribution from the following organizations and stormwater professionals:

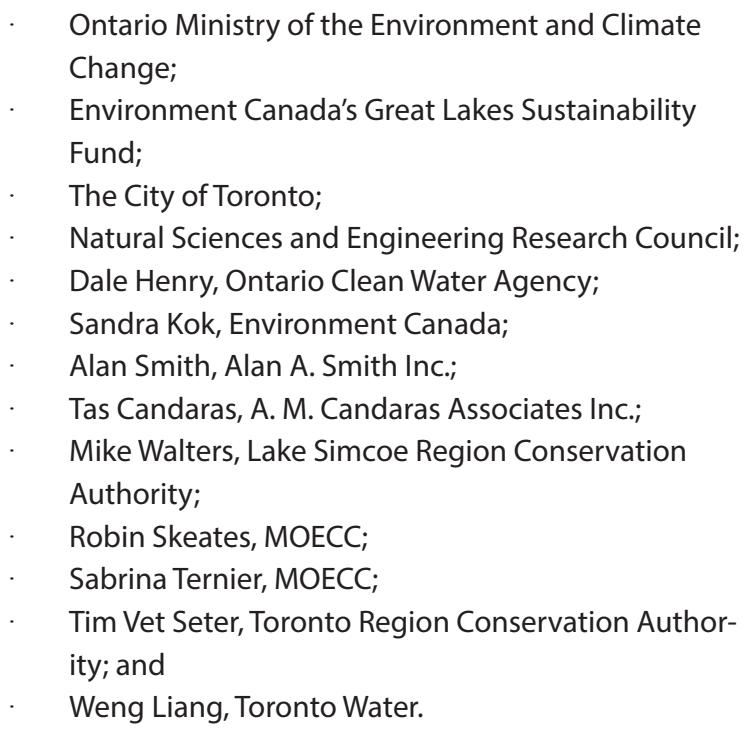

\section{References}

Alan A. Smith Inc. 2009. Microcomputer interactive design of urban stormwater systems (MIDUSS). Dundas, Ontario: Alan A. Smith Inc.

Candaras, A. M. 1997. City of Etobicoke Exfiltration and Filtration Systems: Final report to Environment Canada Great Lakes Cleanup Fund. Burlington, Ontario: A. M Candaras Associates Inc.

Karakis, N. 1999. Evaluation of the Etobicoke exfiltration system. Toronto: Ryerson University. B.A.Sc. Thesis, Department of Civil Engineering.

Li, J. and J. Tran. 2015. Planning and Design Manual of the Etobicoke Exfiltration System for Stormwater Management. Toronto: Ryerson University, Department of Civil Engineering.

Liu, H. (2015). Modeling of the Etobicoke Exfiltration System using PC-SWMM. Toronto: Ryerson University. Master's Thesis, Department of Civil Engineering.

MoE. 2003. Stormwater Management Planning and Design Manual. Toronto: Ministry of the Environment (now Ministry of the Environment and Climate Change).

Ternier, S. 2013. Review of Stormwater Management in Ontario and a Case Study on the Etobicoke Exfiltration. Toronto: Ryerson University. Master's Thesis, Environmental Applied Science and Management Program. 